\title{
Isolation, Identification and Characterization of Daucosterol from Root of Mangifera Indica
}

\author{
NNA prince Joe* \\ Department of Chemistry, Faculty of Pharmacy, University of Port Harcourt, Nigeria \\ *Corresponding author: NNA Prince Joe, Department of Chemistry, Faculty of Pharmacy, Organic \& Medicinal Chemistry \\ Research group, Ignatius Ajuru University of Education, P.M.B.5047, Port Harcourt, Nigeria.
}

\begin{tabular}{|c|c|}
\hline ARTICLE INFO & ABSTRACT \\
\hline Received: August 20, 2020 & Medicinal plants are sources of therapeutic means for man several years ago till date. \\
\hline Published: August 27, 2020 & $\begin{array}{l}\text { It has been of concern in research for new agents for treatment of both emerging and } \\
\text { existing ailments as a result of short comings of existing synthetic drugs. In contributing }\end{array}$ \\
\hline $\begin{array}{l}\text { Citation: NNA Prince Joe. Isolation, Iden- } \\
\text { ification and Characterization of Daucos- } \\
\text { erol from Root of Mangifera Indica. Bi- } \\
\text { omed J Sci \& Tech Res } 29(5)-2020 . \text { BJSTR. } \\
\text { MS.ID.004857. }\end{array}$ & $\begin{array}{l}\text { medicinal agents from root of Mangifera indica. The powdered plant part was extracted } \\
\text { with hexane and ethyl acetate successively using soxhlet apparatus. These extracts were } \\
\text { fractionated in silica gel column and using varying ratios of hexane and ethyl acetate and } \\
\text { fractions obtained were observed using thin layer chromatography in different solvent } \\
\text { systems of hexane, ethyl acetate and detecting reagents such as iodine vapour, UV-lamp } \\
\text { and H2S04. Based on the Rf values obtained from the TLC, the } 50 \text { fractions obtained were } \\
\text { pooled to } 5 \text { and coded as NPJS } 1-2,3-4,5-6,7-8,9-10 \text { respectively. The colourless coded } \\
\text { compounds were subjected to melting point determination and spectroscopic analysis } \\
\text { (proton and carbon-NMR) as well as HMBC, HSQC and COSY. The result showed that } \\
\text { NPJS 3-4 was a Daucosterol. The findings from this result indicates that Daucosterol has } \\
\text { never been reported from this part of the plant. }\end{array}$ \\
\hline
\end{tabular}

\section{Introduction}

The use of plants by man is traceable to their usefulness in producing varieties of drugs, foods, as source of oxygen for man and animals, raw materials for many industries. Plants have proved to be the most useful in curing different diseases and are useful in pharmaceutical industries because of some chemical substances. These chemical substances include steroids, terpenes, flavonoids, alkaloids, tannins, glycosides, phenols, anthraquinones, carotenoids and saponins. These chemical substances are called phytochemicals or secondary metabolites [1]. Phytochemicals are biologically active substances that account for the medical ability of plants which serve as plant protective agents against various diseases and contribute to plants physical features such as aroma, colour and taste. The phytochemicals in plants serve as a protecting tool against environmental risks such as pathogenic attack, any forms of pollution, drought, UV exposure and enhance their usefulness in ethno medicine [2]. The study of plants has remained the interest point over the years of many Phyto-Chemists. Though, the detection of useful clinical products from plant sources has been achieved partially and over 400 novel drugs recognized for viable use over 10 consecutive years, of which over 25 were new natural products and about 130 were improved natural products $[3,4]$. Mangifera indica is a member of group Mangifera and family Anacardiaceae, otherwise known as Mango family. It is made up of 30 genetic kind of the tropical edible fruit trees in the flowering plant from the family Anardiaceae with Mangifera indica been the most predominant class. Mangifera indica species has been described for their tradomedical uses for the management of syphilis, anemia, diabetes, diarrhea, ulcer, fever, and urinary tract infection [5]. Plant stigmastanes have been reported for their antitumor, antidiabetic and anti-inflammable effects and cholesterol lowering [6]. This study, therefore, investigate the root of Mangifera indica with the aim of isolating, identify and characterizing bioactive compounds responsible for its ethno-medical uses. 


\section{Materials and Methods}

\section{Plant collection and Preparation}

Roots of Mangifera indica were obtained in June, 2019 from Bunu Tai, Tai Local Government Area, Rivers State, Nigeria and authenticated at the Department of Plant Science and Biotechnology, University of Port Harcourt and deposited at the Departmental Herbarium with voucher specimen No: UPH/2019/MIR/231. The root was kept clean with distilled water and dehydrated at room temperature for two weeks, crushed with the aid of a pestle and mortar and deposited in a tight basin, thereafter, moved to the laboratory for further experimentation.

\section{Sample Extraction}

Pulverised root of the sample $(2 \mathrm{~kg})$ was serially extracted using soxhlet apparatus (n-hexane and ethyl acetate). Surplus solvent was aloof below reduced pressure to give unfinished residue extract labelled NPJS and kept in the refrigerator. The ethyl acetate extract was dissolved in n-hexane and chloroform (1:1) and reflux for three hours then filtered.

\section{Chromatographic Separation}

The filtrate was exposed to column chromatography via silica gel by means of stationary phase. The solvent system comprised of $n$-hexane in mixture with ethyl acetate. Approximately $30 \mathrm{~mL}$ fractions were taken by gradient elution procedure and elutes were observed using thin layer chromatography of 30:70 of ethyl acetate and hexane solvent ratio. The fractions displaying related Rf value after envisioning by UV-lamp were assembled together. Collected fractions were confirmed with thin layer chromatography by spurting with anisaldehyde-sulphuric acid and the pink colour spots were established as stigmastanes. Fractions agreeing to $\mathrm{Rf}$ values were assembled, washed with acetone, and subjected to TLC with hexane-ethyl acetate 8:2 (v/v). Fractions NPJS 3-4 (23.4 $\mathrm{mg}$ ) were discovered to have crystals which were independently washed and repeated with hexane $(35 \mathrm{ml})$. TLC with hexane and dichloromethane (1:2) gave a distinct spot with Rf value 0.47 . The purified fraction was labelled NPJS 3-4. This was established using Keller-kiliani reaction and Liebermann-Burchards test as described [7].

\section{Spectroscopic Characterization}

The purified coded fraction was subjected to melting point determination, IR, and spectroscopic analysis (Proton and CarbonNMR) as well as HMBC, HSQC and COSY to explain the structure of the compound. The spectra $1 \mathrm{H}, 13 \mathrm{C}, 2 \mathrm{D}$ NMR were verified with the aid of acetone as solvent on a Bruker Avance 3 spectrophotometer at University of Strathclyde, Glasgow, Scotland, United Kingdom.

\section{Results and Discussion}

The spectroscopic characterization result of NPJ 3-4 (Daucosterol) from Mangifera indica root are reported in (Tables 1\&2) (Figure 1).

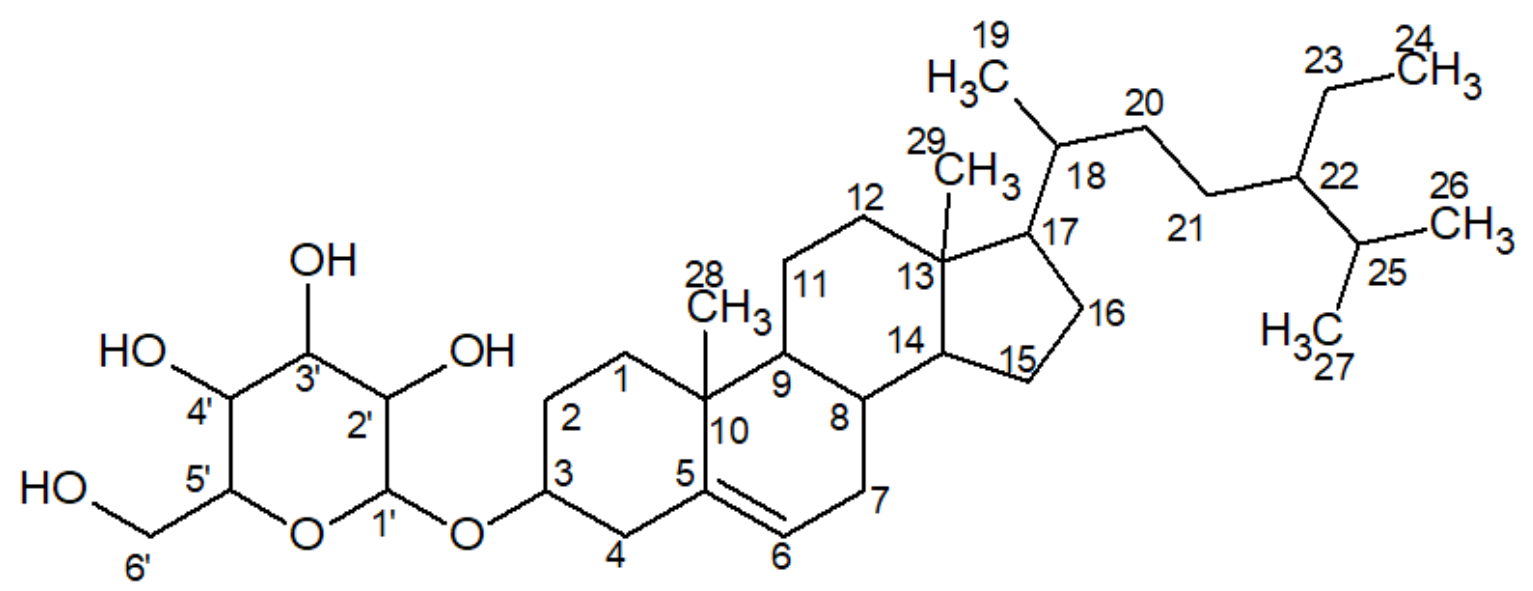

Figure 1: NPJS 3-4 as Daucosterol.

Table 1: ${ }^{1} \mathrm{HNMR}$ and $13 \mathrm{C}$ NMR chemical shifts for NPJS 3-4.

\begin{tabular}{|c|c|}
\hline Spectroscopic technique & Data \\
\hline $1 \mathrm{R}(\mathrm{cm}-1)$ & $3450,2850,1095,1379,836$ \\
\hline $\mathrm{Rf}$ & 0.47 \\
\hline $\mathrm{Mp}$ & $\delta 1.00,1.24,2.88,2.33,5.30,1.77,0.91,1.05,1.24,0.75,4.32,2.89,3.28,3.05,3.28,4.54 \mathrm{ppm}$ \\
\hline 1HNMR(Acetone) & $\begin{array}{c}\delta 7.02,29.6,76.7,40.3,139.5,121.4,31.8,29.6,51.1,34.6,21.4,40.3,40.5,55.7,21.5,28.6,55.7,12.6, \\
19.3,37.0,21.6,34.5,25.4,45.6,28.6,19.3,13.4,21.5,11.6,101.3,73.5,76.7,70.6,76.8,61.6 \mathrm{ppm}\end{array}$ \\
\hline
\end{tabular}


Table 2: Comparison of NMR data for NPJS: 3-4 with literature.

\begin{tabular}{|c|c|c|c|c|}
\hline \multirow{2}{*}{ C-position } & \multicolumn{2}{|c|}{ Experimental } & \multicolumn{2}{|c|}{ Literature Peshim and Kar (2017). } \\
\hline & ${ }^{1} \mathrm{H}(\delta)$ & ${ }^{13} \mathrm{C}(\delta)$ & ${ }^{1} \mathrm{H}(\delta)$ & ${ }^{13} \mathrm{C}(\delta)$ \\
\hline 1 & 1.00 & 37.02 & 1.00 & 36.79 \\
\hline 2 & 1.24 & 29.6 & 1.26 & 29.23 \\
\hline 3 & 2.88 & 76.7 & 2.98 & 76.85 \\
\hline 4 & 2.33 & 40.3 & 2.26 & 39.28 \\
\hline 5 & - & 139.5 & & 140.4 \\
\hline 6 & 5.30 & 121.4 & 5.35 & 121.2 \\
\hline 7 & 1.77 & 31.8 & 1.73 & 31.38 \\
\hline 8 & & 29.6 & & 31.26 \\
\hline 9 & & 51.1 & & 49.55 \\
\hline 10 & & 34.6 & & 36.18 \\
\hline 11 & & 21.44 & & 20.56 \\
\hline 12 & & 40.3 & & 38.26 \\
\hline 13 & & 40.5 & & 41.82 \\
\hline 14 & 0.91 & 55.7 & 0.95 & 56.13 \\
\hline 15 & 1.05 & 21.5 & 1.05 & 23.83 \\
\hline 16 & 1.24 & 28.6 & 1.25 & 27.76 \\
\hline 17 & & 55.7 & & 55.38 \\
\hline 18 & 0.75 & 12.6 & & 11.64 \\
\hline 19 & & 19.3 & & 19.07 \\
\hline 20 & & 37.0 & & 35.45 \\
\hline 21 & & 21.4 & & 18.58 \\
\hline 22 & & 34.5 & & 33.29 \\
\hline 23 & & 25.4 & & 25.36 \\
\hline 24 & & 45.6 & & 45.09 \\
\hline 25 & & 28.6 & & 28.64 \\
\hline 26 & & 19.3 & & 19.69 \\
\hline 27 & & 13.4 & & 18.89 \\
\hline 28 & & 21.5 & & 22.06 \\
\hline 29 & & 11.6 & & 11.75 \\
\hline $1^{\prime}$ & 4.32 & 101.3 & 4.20 & 100.75 \\
\hline $2^{\prime}$ & 2.89 & 73.5 & 2.89 & 73.42 \\
\hline $3^{\prime}$ & 3.28 & 76.7 & 3.27 & 76.86 \\
\hline $4^{\prime}$ & 3.05 & 70.6 & 3.00 & 70.04 \\
\hline $5^{\prime}$ & 3.28 & 76.8 & 3.06 & 76.72 \\
\hline $6^{\prime}$ & 4.54 & 61.6 & 4.58 & 62.82 \\
\hline
\end{tabular}

\section{Characterisation of compound NPJS 3-4 as Daucosterol}

The fraction coded NPJS 3-4 was obtained from the ethyl acetate extract of Mangifera indica root as violet colour from sephadex column and gave an Rf value of 0.47 on thin layer chromatography. The IR spectrum of the compound showed a broad band in the region $3450 \mathrm{~cm}^{-1}$ indicating presence of $-\mathrm{OH}$ of glucoside linkage [8]. The absorption observed at $2958-2850 \mathrm{~cm}^{-1}$ was allotted to asymmetric aliphatic $-\mathrm{CH}$ stretching of $\mathrm{CH} 3$ and $\mathrm{CH} 2$ groups. A band observed at $1095 \mathrm{~cm}^{-1}$ was assigned to $\mathrm{C}-\mathrm{O}-\mathrm{C}$ linkage. The weak absorption observed at $1664 \mathrm{~cm}-1$ was assigned to $(\mathrm{C}=\mathrm{C})$ stretching. However, three other bands were observed at 1452, 1379 and $836 \mathrm{~cm}^{-1}$. The ${ }^{1} \mathrm{H}-\mathrm{NMR}$ spectrum of compound NPJS 3-4 showed a chemical shift in the range $\delta \mathrm{H}$ 0.79-0.97 suggesting presence of methyl protons. A singlet observed at $\delta \mathrm{H} 0.75$ was assigned to methyl protons. The proton attached to olefinic linkage was observed at $\delta \mathrm{H} 5.30$. The signals observed at $\delta \mathrm{H} 0.79$ and $\delta \mathrm{H} 0.91$ were assigned to methyl groups of isopropenyl moiety (Peshin and Kar, 2017). Methyl proton was observed at $\delta \mathrm{H} 0.91$ with coupling constant $\mathrm{J}=6.4 \mathrm{~Hz}$. The proton of glucose was observed at $\delta \mathrm{H} 2.88-4.32$ as a multiplet. 
The proton of CH-group of glucoside was observed at $\delta \mathrm{H} 4.40$. Proton was observed at $\delta \mathrm{H} 2.88$ the hydroxyl protons of the sugar moiety showed resonance at $\delta \mathrm{H}$ 3.56-3.63 [9].

The 13C-NMR spectrum of the compound indicated 35 carbon signals of which six were for the sugar moiety and 29 attributed to the aglycone moiety. The carbon signals observed at $\delta \mathrm{C} 61.6$ (C-6'), $\delta \mathrm{C} 70.6$ (C-4'), $\delta \mathrm{C} 73.5$ (C-2'), $\delta \mathrm{C} 76.8$ (C-5'), $\delta \mathrm{C} 76.70$ (C-3') and $\delta \mathrm{C}$ 101.3 (C-1') were well stable with those of glucose moiety (Lee et al; 2004). The aglycone moiety signals were observed at $\delta \mathrm{C} 139.5$, $\delta \mathrm{C} 121.4, \delta \mathrm{C} 76.7, \delta \mathrm{C} 55.7, \delta \mathrm{C} 55.7, \delta \mathrm{C} 51.1, \delta \mathrm{C} 45.6, \delta \mathrm{C} 40.5, \delta \mathrm{C}$ $40.3, \delta \mathrm{C} 40.3, \delta \mathrm{C} 37.02, \delta \mathrm{C} 34.6, \delta \mathrm{C} 36.0, \delta \mathrm{C} 37.0, \delta \mathrm{C} 34.5, \delta \mathrm{C} 31.8$ , $\delta \mathrm{C} 29.6, \delta \mathrm{C} 29.6, \delta \mathrm{C} 28.6, \delta \mathrm{C} 28.6, \delta \mathrm{C} 25.4, \delta \mathrm{C} 21.5, \delta \mathrm{C} 21.5, \delta \mathrm{C}$ $21.44, \delta \mathrm{C} 19.3, \delta \mathrm{C} 19.3, \delta \mathrm{C} 13.4, \delta \mathrm{C} 21.4, \delta \mathrm{C} 11.6$ and $\delta \mathrm{C} 12.6$ (Table 1). The chemical shift at $\delta C 19.3$ and $\delta C 21.4$ were allotted to two methyl groups. The signals observed at downfield $\delta \mathrm{C} 12.6, \delta \mathrm{C} 19.3$ and $\delta \mathrm{C} 21.4$ were given to angular methyl group moiety associated to $\mathrm{C}-18, \mathrm{C}-19$, and $\mathrm{C}-21$. The signals at $\delta \mathrm{C} 139.5, \delta \mathrm{C} 34.6$ and $\delta \mathrm{C} 40.5$ were assigned to the quaternary carbons at C-5, C-10, and C-13. Signals observed at $\delta C 29.6, \delta C 51.1$ and $\delta C 55.7$ were assigned to carbon at C-8, C-9, and C-14, respectively. An upfield chemical shifts at $\delta \mathrm{C} 37.02, \delta \mathrm{C} 29.6, \delta \mathrm{C} 40.3, \delta \mathrm{C} 31.8, \delta \mathrm{C} 51.1, \delta \mathrm{C} 21.44, \delta \mathrm{C} 40.3$ $, \delta \mathrm{C} 55.7, \delta \mathrm{C} 21.5 \mathrm{ppm}, \delta \mathrm{C} 28.6$ and $\delta \mathrm{C} 55.7$ may be due to cyclohexyl and cyclopentyl of A, B, C and D-rings. Chemical shift at $\delta \mathrm{C} 37.0, \delta \mathrm{C}$ 76.70 and $\delta C 101.3$ could be ascribed to carbon of cyclic linkage and anomeric carbon, respectively. The $1 \mathrm{H}$ and 13C-NMR spectra data were in line with literature reports (Peshim and Kar, 2017) for a polyphenol with glucose and aglycone moieties, thus, fraction NPJS 3-4 was identified as stigmastane commonly called $\beta$-sitosterol-3O- $\beta$-D-glucoside (Daucosterol) [10].

\section{Conclusion}

The isolated compound has been reported for its antibacterial and antifungal activities and thus could also serve as useful precursor in the synthesis of drugs to treat diseases caused by some clinical pathogens which justifies the ethno medical claims of this plant uses for treatment of some bacteria caused diseases.
However, this study is the first to prove the presence of Daucosterol in this part of the plant.

\section{Acknowledgement}

The author is thankful to Tertiary Education trust fund (TETfund) for sponsoring the research work. I am also grateful to the University of Stratchlyde, United Kingdom for providing facilities for this study leading to isolation and characterization of the compound.

\section{References}

1. Abbas I, Ahmed AA, Abdul MI, Muhammad KU, Abubakar CS (2019) Bark extracts of Dacryode edulis and their Anti-pathogenic Activity against some clinical Isolates. Chemistry Research Journal 4(2): 54-58.

2. Lee KH, Min, YD, Choi SZ, Kwon HC, Lee KC (2004) A new Sesquiterpene lactone from Artemisia rubripesnakai. Arch Pharmaceutical Research 27(10): 1016-1019.

3. Nna PJ, Tor Anyiin TA, Igoli JO (2019) Phytochemical studies on the Stem Bark Extracts of Dacryodes edulis and their Anti-Pathogenic activity against some Common Clinical Isolates. Chemistry Research Journal $4(2)$ : 54-58.

4. Nwokonkwo DC (2014) The Phytochemical study and antibacterial activities of the seed extract of Dacryode edulis (African native pea). African Journal of Science Industrial Research 5: 7-12.

5. Peshim T, Kar HK (2017) Isolation and characterization of $\beta$-sitosterol-3-0- $\beta$-D-glucose from the extract of the flowers of Viola odorata. British Journal of Pharmaceutical Research 16(4): 1-8.

6. Phytochemical Evaluation, Antimicrobial and Mineral Analysis of Senna occidentalis

7. Shan T, To W, Ahmed H (2017) Magnetic resonance imaging in the early detection of prostate Cancer and review of the literature on magnetic resonance imaging-stratified clinical pathways. Expert Review of Anticancer Therapy 17(12): 1159-1168.

8. Sofowora EA (1993) Medicinal plants and traditional medicine in Africa. In Sofowora EA (Eds.), (2 ${ }^{\text {nd }}$ edn.), Spectrum books Ltd, Ibadan, Nigeria 2(3): 289 .

9. Tor Anyiin TA, Akpuaka MU (2011) A Triterpenoid from stem Bark of Sterculia setigera Del. Journal of Chemical Society of Nigeria 36 (2).

10. Tor Anyiin TA, Igoli JO, Anyam JN (2016) Studies on Dacryodes edulis III: Isolation and characterization of Gallic acid from methanolic extract of raw (Untreated) seed of Dacryodes edulis and its Antimicrobial properties. Journal of chemical society of Nigeria 40(1): 6-9.

\section{ISSN: 2574-1241}

DOI: $10.26717 / B J S T R .2020 .29 .004857$

NNA Prince Joe. Biomed J Sci \& Tech Res

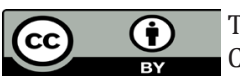

This work is licensed under Creative Commons Attribution 4.0 License

Submission Link: https://biomedres.us/submit-manuscript.php

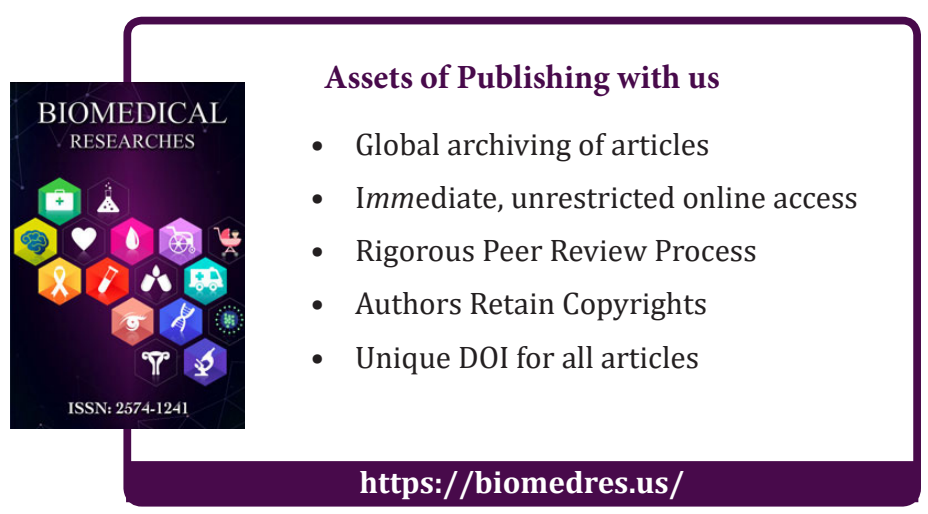

Copyright@ NNA Prince Joe | Biomed J Sci \& Tech Res | BJSTR. MS.ID.004857. 